\title{
RECENTLY DISCOVERED BRONZE WAGON MODELS FROM ŞANLIURFA, SOUTHEASTERN ANATOLIA
}

\begin{abstract}
Özet
1999 yılında, güvenlik kuvvetleri tarafindan müsadere edilen boğa koşulu üç tunç araba modeli ve bir çift boğa heykelciği Şanlıurfa Müzesi'nde korumaya alındı. Elde edilen bilgilere göre, bu modellerin Suruç ilçesinin hemen kuzeybatısındaki Abamor köyü civarında bir mezarlıktan çıkarıldığı anlaşıldı. Her biri farklı biçimde yapılmış bu araba modelleri, Önasya'da çeşitli yerlerde bulunduğu iddia edilen araba modellerine ilişkin, hem form hem de teknik bakımdan yeni özellikler kazandırmaktadır. Abamor 1 nolu modeli, örneğini imdiye kadar sadece pişmis toprak araba modellerinden tanıdığımız ve Önasya'da bulunmuş üstü kapalı tek bronz araba modelidir. 2 ve 3 nolu modeller de, diğer araba modellerinde görülmeyen bazı yeni teknik özellikler göstermektedir.
\end{abstract}

The early history and sources of information for four-wheeled vehicles in the ancient Near East and Transcaucasia have been widely discussed by Salonen, Childe, Piggott, and Littauer and Crouwel. ${ }^{1}$ Özgen who has published a group of terracotta vehicles found in the Suruç region, presented new evidences from southeastern Anatolia of the late third millennium. ${ }^{2}$ His study was followed by Littauer and Crouwel's article about a related model found in Syria. ${ }^{3}$ On the other hand, Özgüç enlightened us about the first actual spoked vehicle and the representational counterparts in the Assyrian Colony Period. ${ }^{4}$ Recently a monumental study edited by Raulwing with Littauer and Crouwel in 2002 collected selected writings about the elements of ancient transportation. ${ }^{5}$

Metal models of full-size wagons have been reviewed with respect to their form, technique,

\footnotetext{
${ }^{1}$ See Littauer et al. 2002 for rich references.

2 Özgen 1986.

${ }^{3}$ Littauer - Crouwel 1990.

${ }^{4}$ Özgüç 2001.

${ }^{5}$ Littauer et al 2002
}

and material as well as function in detail. ${ }^{6}$ However the dating and authenticity of these artifacts have long been debated, since none of them was found in a systematic excavation. In addition to the authenticity of these artifacts, the dating was another speculative problem. ${ }^{7}$ Representations, which are seen in seals, objects of art, and even terracotta models, are not thoroughly helpful in dating.

In 1999, three bronze wagon models with draught animals and a pair of bulls were acquired by the Şanliurfa Museum (Fig. 1). According to the Museum records and the data gained from villagers, the models were dug out in a necropolis near Abamor Höyük, which lies in the northwest of Suruç sub-province (map. 1). The villagers implied that in the previous years, more than twenty models were found in this region and illegally sold to dealers. Özgen,

\footnotetext{
${ }^{6}$ For a general bibliography of other terracotta models found in the region see: Liebowitz 1988; Bollweg 1999.

${ }^{7}$ Piggott 1968, 273; Littauer - Crouwel 1973, 102, $121 \mathrm{ff}$.
} 
who published a group of terracotta wagon models, kept in the Gaziantep and Adana Museums reported that they were also found in around Suruç. ${ }^{8}$

The Abamor models offer important evidence about the origin, technique and style of the previously published wagon models which are reported to have been discovered in North Syria, southeastern Anatolia ${ }^{9}$ and central Anatolia ${ }^{10}$, then dispersed to the worldwide museums and private collections.

The metal models are much more helpful than clay models in understanding the various construction elements of actual full-size ancient wagons, because of the more detailed workmanship, especially in the frames and superstructure. ${ }^{11}$ However, one must also take into consideration that these models do not completely reflect the structure of the actual vehicles. ${ }^{12}$ A detailed analysis of the elements of the models will help us to compare these model wagons to the real-life ancient wagons.

\section{Catalogue}

\section{No.1: A. Wagon:}

Dimensions:

Length: $55 \mathrm{~cm}$,

The distance between the wheels: $17,5 \mathrm{~cm}$,

Length of the axle: $21 \mathrm{~cm}$,

Height of the wagon: $16 \mathrm{~cm}$.

The first model is a four-wheeled covered wagon. The front is left open, while the back is covered with a bronze rectangular plate with an oval-shaped top (Fig. 1: in the middle). The edges of the rear cover plate are bent forward to lock the roof of the box. Two rivet holes on both sides and one at the top fix the rear plate to the main cover. The floor of the wagon is made of a separate plate. Its edges are slightly bent upward (Fig. 2). The

\footnotetext{
${ }^{8}$ Özgen 1986, 165.

${ }^{9}$ Piggott 1968, 273.

${ }^{10}$ Littauer-Crouwel 1973, 102.

${ }^{11}$ Ibid. 109.

${ }^{12}$ Ibid. 117.
}

one-piece roughly rectangular cover is bent and placed over the floor and fixed by three rivets on both sides. The front of the cover is higher than the rear.

Two axles are riveted to the bottom of the floor (Fig. 3 ). The axles, rectangular in section, are flattened on the rivet holes, rounded where the wheels turn. The ends are bent backward to hold on the solid disk wheels with spool-like navels.

Two overlapping roughly rectangular plates, of which one ends slightly elongated (Fig. 3 ) are attached from their wide ends to the floor by two rivets in the front. The fork-shaped end of the curved pole, rectangular in section, is attached to the elongated ends of these plates by a single rivet.

The tip of the pole is curved and bent to form a hole. The yoke is inserted through this hole. The centre of the yoke, rectangular in section is pinched to fit to the pole. The ends of the yoke are also curved upward and then downward in order to be placed well over the necks of the bovines.

\section{B. Bulls:}

a: Dimensions:

Length: $24 \mathrm{~cm}$, height: $12,1 \mathrm{~cm}$, width: $4,7 \mathrm{~cm}$.

The distance between the two horns: $11 \mathrm{~cm}$.

Cast of solid bronze (Fig. 4). Casting traces are still visible.

The first bull has long horns with pointed tips. It has a slender body. The elongated ears are joined to the horns around their bases. The flat head, broad forehead and straight-cut muzzle deserve attention. The eyes are placed on the sides, and then pierced. The mouth is shown by a deep indentation. The nose is vertically pierced to take a line, and is still preserved. The respectively short neck has a shape of a rectangular prism of which the edges are rounded. Two flattened bar-shaped forelegs start just from the end of the neck. The muscles are not emphasized clearly. The hooves are not indicated either. The genitals are not shown. A long inserted tail has a pointed tip. The upper end of the tail is still visible.

b: Dimensions:

Length: $27,8 \mathrm{~cm}$, height: $13,5 \mathrm{~cm}$, width: $4,5 \mathrm{~cm}$.

The distance between the two horns: $11 \mathrm{~cm}$.

Almost identical to bull no. a. The main difference is the forward running bodyline. The leg curve is strongly emphasized. The tail is inserted slightly diagonally. 


\section{No. 2: A. Wagon:}

Dimensions:

Length: $54 \mathrm{~cm}$,

The distance between the wheels: $24 \mathrm{~cm}$,

Length of the axle: $21 \mathrm{~cm}$,

Height of the wagon: front: $17 \mathrm{~cm}$; rear: $14,5 \mathrm{~cm}$,

Diameter of the wheels: front: $12 \mathrm{~cm}$; rear: $11 \mathrm{~cm}$,

Width of the wagon with the bulls: $30 \mathrm{~cm}$.

The second model is another four-wheeled wagon with railwork cage and front and side screens (Fig. 5). Inside the screens, the rails are attached to the floor (Fig. 6). Side screens run higher to the front. The rear is open without screen. The front screen is fixed to the $\cap$-shaped vertical bar, which is round in section, by tearing apart a rectangular section in the centre. The lines are also used to lash this screen. The sheet-metal screens are placed outside the railing. These originally must have been lashed together by wires as observed by the piercings on the upper corners of each screen. The railwork is made up of vertical and horizontal bars rectangular in section. Two thicker horizontal bars at the top of the rails are tied to the front bar by turning around it, and attached to the rear rails before the last verticals. These two bars are tied by another shorter horizontal bar at the back. The vertical rail bars are inserted into the upper horizontal thick and flattish bars and then bent. The floor of the wagon is also pierced to hold these vertical bars (Fig. 7). The rear rail has another horizontal flattish bar at the bottom of the wagon (Fig. 6). The rectangular floor has three small rectangular projections in the front; one in the middle and two on the sides. These projections are formed by cutting and alternatively bending the floor plate. The draught pole, which is square in section, forks as it approaches the box. The pole is fastened to the central projection (Fig. 7).

The axles, rectangular in section, are fixed to the bottom of the floor by the thick vertical bars of the railwork, which are inserted to the floor and then bent at the bottom (Fig. 7). The axles hold the solid disc-shaped wheels with the spool-like central hole by bending up at the ends (Fig. 6).

The straight pole, which is bent at the end, measures 24 $\mathrm{cm}$ (Fig. 5). The yoke is pinched and flattened in the middle to hold the pole. The yoke, square in section, is flattened at the ends. It is curved and bent to fit over the neck of the bulls. The yoke must have been tied to the bulls by tiny square-sectioned metal lines and rings still kept on the necks of the animals.

\section{B. Bulls:}

a: Dimensions:

Length: $18,4 \mathrm{~cm}$, Height: 12,5 cm, Width: $3,8 \mathrm{~cm}$.
Cast of solid bronze (Fig. 5, 8).

The first bull has short and blunt horns. The tip of the right horn is broken and missing. The forehead tapers through the muzzle. Just under the horns, horizontally placed ears are divided into two by a horizontal line. No fills are traced inside the protruding eye sockets. Two holes on both sides of the muzzle for harnessing, do not come across each other. The nostrils are shown by two holes on the muzzle. A horizontal shallow groove under the nostrils represents the mouth. A straight ridge, which begins just under the jaw and descends between the forelegs indicates the dewlap. The end of the yoke must have been placed over the small hump shown as a semiglobular projection on the neck above the forelegs. The slender body has fleshier legs. The knees of the forelegs are emphasized. The hooves are indicated by an indentation. How the tail is attached to the body, which is square in section and tapering to the tip, is not clear. Genitals are represented naturalistically. The twisted metal lines still on the neck must have been used for fixing the yoke to the bovines and harnessing.

b: Dimensions:

Length: 18,5 cm, height: $12,5 \mathrm{~cm}$, width: $4 \mathrm{~cm}$.

Identical to no a. Cast of solid bronze. Both horns are preserved in good condition.

\section{No.3: A. Wagon:}

Dimensions:

Length: $32 \mathrm{~cm}$, Length of the axle: $8 \mathrm{~cm}$.

This model is found in very poor condition (Fig. 9). The front end is slightly higher than the rear. The front panel is tied to the $\cap$-shaped flat bar (Fig. 10). This bar is supported by an oblique stick, round in section, on both sides. The side screens are fixed to the floor and this $\cap$-shaped bar. The rear of the wagon is covered with a rectangular sheet, which is folded into two to hold the inserted ends of the side screens. This sheet is tied at the top by a thin metal wire in two places. The floor of the wagon is supported by a thin rectangular-sectioned bar which is placed horizontally inside the wagon.

The wheels are put on the square-sectioned axle. The axles are inserted through the floor sides, inside the box. The ends of the axle are divided lengthwise into two and then bent backward for fixing the wheels.

The fork-shaped and square-sectioned pole is fastened to the holes pierced into the front curtain and floor (Fig. 11). The yoke, which is also square in section, is fastened to the pole. The ends of the yoke are slightly curved. 
B. Bulls:

a: Dimensions:

Length: $12 \mathrm{~cm}$, height: $6 \mathrm{~cm}$, width: $4,2 \mathrm{~cm}$.

Cast of solid bronze (Fig. 12). The upwardly bent horns are short. It has a slightly convex forehead and protruding muzzle. A metal wire is preserved in the nostrils. The mouth is indicated by a horizontal groove. One of the oval-shaped flat ears is missing. It has an elongated body with short and blunt legs. The tiny tail is inserted into the body. Hooves are shown clearly.

b: Dimensions:

Length: $12 \mathrm{~cm}$, height: $5,5 \mathrm{~cm}$, width: $4,2 \mathrm{~cm}$.

Identical to1 no a. Both ears are preserved.

4. A pair of bovines: (Fig. 1: on the left)

a: Dimensions:

Length: $10,3 \mathrm{~cm}$, height: $2,9 \mathrm{~cm}$, width: $3,3 \mathrm{~cm}$.

It has slender body with short horns, and a tail. Almost identical with the bulls of wagon 3. It is preserved in good condition.

b. Same as no. a. Front half of the animal is missing. It has a short and flattened tail.

\section{Remarks}

The three metal wagon models found in Abamor differ from each other and have some unique features that have not been seen on published metal models. We derive more detailed knowledge about the form and technique from the Abamor wagons than from the other published models.

Although all of the Abamor wagons have rectangular cases, they are differentiated by their frames. No. 1 is the first covered metal wagon model without the railwork. This type is only known from the terracotta models. A small terracotta wagon model from Tepe Gawra Stratum VI with a double lug in the front and another terracotta model from Selenkahiye are the only four-wheeled tented wagons discovered in scientific excavations dated to the last quarter of the third millennium BC. ${ }^{13}$ The main difference is the uncovered rear of the Tepe Gawra wagon. Another terracotta four-wheeled covered wagon with closed rear similar to the Abamor model was said to be found in Hamman, south of Carchemish in Syria. ${ }^{14}$ A similar terracotta wagon model that was acquired by the Gaziantep Museum was reportedly found in Suruç..$^{15}$

The cover of the Abamor wagon no. 1 seems to drop slightly towards the rear. This feature was also observed by Littauer and Crouwel in evaluating a terracotta model in a private collection in London as careless workmanship "rather than a faithful copying of a real condition". ${ }^{16}$ However, the same feature can also be seen in the Hamman and Gaziantep Museum wagons and indicates a common practice for the actual wagons. ${ }^{17}$

Abamor models nos. 2 and 3 are similar to each other with their uncovered cases, but differ in the shapes of the railing and screens. The wagon model no. 2 with side screens and railwork is similar to the Littauer and Crouwel's Anatolian group nos. 3, 6 and a, c, d, e. ${ }^{18}$ The side screens of Abamor no. 2, together with the railwork may also indicate detachable side screens of the full-size actual wagons. ${ }^{19}$ The use of

13 Speiser 1935, 73-74, 163, 192, pl. XXXV, 2; Piggott 1968, 273; Littauer - Crouwel 1974, 22, 31; Liebowitz 1988, 19-21; Strommenger 1990, 297, 301; Zettler 1996, 19; Strommenger Kohlmeyer 1998, 86-87; Strommenger et al. 1987, 47,50; Moorey 2001, 346.

${ }^{14}$ Littauer - Crouwel 1974, 20, fig. 1.

${ }^{15}$ Gaziantep Museum Inv. No. C. 118.58.74. Fourwheeled wagon. Acquired from Tekin Özharat in Suruç. Length of the wagon excluding the modern wheels: $11.2 \mathrm{~cm}$. Height: $10 \mathrm{~cm}$. Cream colored paste. Decorated with incisions on the tilt. I thank my colleague F. Bulgan for her generous help.

${ }^{16}$ Littauer - Crouwel 1974, 33.

${ }^{17}$ See also Liebowitz 1988, 20; Strommenger 1990, 298, pl. 99.

${ }^{18}$ See Littauer-Crouwel 1973, 105-107.

${ }^{19}$ Ibid. 33. 
side screens together with the railwork makes one think that other models found with only the railwork also may have once had side screens that are no longer preserved.

The box of Abamor no. 3 without the railwork is not known from any other models previously published. The formation of the rear curtain of the wagon is also a unique construction technique.

The breastworks of Abamor wagons do not have a double aperture, which is seen in most seals. ${ }^{20}$

The floors of the Abamor wagons consist of a whole piece of rectangular sheet. In no. 1 and 3 , the longer sides were bent upward to prepare bedding to the side screens. Three projections in front of the floor of wagon no. 2 make it a unique example among the Abamor wagons. This element was discussed by Littauer and Crouwel concerning terracotta wagon in a private collection in London. These three projections were considered an "anomaly" and reviewed as "no relation to reality" or "in some way corresponded to features of actual wagons ... would be the ends of the two side and one centre lengthwise beams of the floor". ${ }^{21}$

The axles of the three wagons are not completely different in their technique and shape. The axles, rectangular in section, widened at the rivet holes. They are rounded by hammering (?) where the wheels turn. The ends are bent backward or split into two and bent to fasten the disk wheels. The axles, especially the front ones, were not intended to move when the wagon or the draught animal changed direction as actual axles do. On nos. 1 and 2, two bars of the railwork or rivets are used as bolts to hold the axle. They prevent the front axle both from revolving and from swiveling. If there were only a single bolt at

\footnotetext{
${ }^{20}$ See the notes in Littauer - Crouwel 1973, 114.

${ }^{21}$ Littauer - Crouwel 1974, 33.
}

the front, as on some Syrian and perhaps on Anatolian wagons, the axles would be inclined to swivel. ${ }^{22}$

The wheels of the three wagons show the same features. They all have spool-like centres on both faces. The diameters differ according to the size of the wagons, but generally they are all proportionally larger than wheels on actual full-size wagons. They all revolve on their axles easily. No linch pins are used to fix the wheels, instead, the end of the axle (as on no. 1) or split (as on nos. 2 and 3) to hold the wheels.

The very tiny rims of the wheels show that they were not intended to be covered with any other material.

Among the three Abamor models and the other published models, the method of fixing the pole to the wagon is unique in Abamor no. 1. As described in detail above, two overlapping rectangular plates (of which one ends slightly elongated) are used to hold the pole (Fig. 3). Their wide ends are attached to the floor of the wagon by two rivets. The fork-shaped end of the pole is attached to the elongated end of this component by a single rivet.

Although the draft poles of models nos. 2 and 3 show minor differences in detail, they are roughly similar to each other. A forkshaped pole fastened to the box is seen on both models. The draught pole of no. 2 is fastened to the central projection at the front by bending the tips of the fork. On the other hand, on no. 3 the pole is fastened by wires to holes pierced into the front curtain and floor.

The yokes are generally round in section, flattened at the ends, curved and then bent to fit over the neck of the bulls. The centre of the yokes is pinched to fit well to the

${ }^{22}$ Littauer - Crouwel 1973, 111 
pole. On no. 1, the yoke is inserted through the hole at the end of the pole as also seen on model no. c of Littauer and Crouwel. ${ }^{23}$ On model no. 2, the yoke is pinched to hold the pole. The yoke of no. 2 must have been tied to the bulls by metal lines found on the necks of the animals.

In reality, unless yoked, these lines would have been attached to nose rings permanently fixed to the bovines' noses in a horizontal position through the nostrils. Instead, the bulls' noses are pierced vertically, as also described by Littauer and Crouwel. The same feature is also seen on a bull found at Horoztepe with the lines in the nose. ${ }^{24}$

The wires found on the breastwork of Abamor wagon no. 2 may indicate the draught lines. On the other hand, the authenticity of the wires found on no. 3 is questionable.

Bulls are the only draught animals yoked to each other and to a draft pole as seen on other models originating from the region. However, the draught animals on the Abamor models also show slight differences in their shapes, sizes and styles. The bovines are crudely rendered with elongated bodies, thin thighs and legs. The sexuality of the animals is clear on model no. 2. This detail was not observed by Littauer and Crouwel on other draught animals. ${ }^{25}$

All the bulls found in Abamor were produced by the same technique, solid-cast, with some elements fixed or inserted. The pointed horns were soldered to the head with great care. In contrast, the pointed tails were simply inserted into a hole opened in the back of the animal. Littauer and Crouwel also noted this workmanship. ${ }^{26}$ In general, the style of the bulls is peculiar to the draught animals of the

23 See Littauer - Crouwel 1973, 107.

${ }^{24}$ Özgüç - Akok 1958, 47, pl. XI/2.

${ }^{25}$ Littauer - Crouwel 1973, 119- 120.

${ }^{26}$ Ibid. 120. metal wagon models, and seems to have no parallels elsewhere in the region. ${ }^{27}$

\section{Concluding remarks}

These recently discovered metal models of wagons add new members and unique features to the corpus of Near Eastern bronze vehicle models. They are also the first group with an exact origin of find location known to us. These finds may also provide evidence for the origin of other previously published metal models said to be found in the North Syria-Anatolia region.

Although all of the Abamor models were found in the same cemetery, it is shown in the above catalogue that they do not form a homogeneous group. As a whole they present a great variety in their shapes. ${ }^{28}$ However, one can infer from their technique and style that they were manufactured in the same period.

In contrast to the similar models found in the region, these three models, were not solid cast except the draught animals. ${ }^{29}$ They were formed by cutting, bending and riveting, or fixing plates and rods.

This Anatolian group of models could easily be considered as utilitarian, with their box construction and draught animals that are suitable for powerful traction. They represent actual wagons designated for farm use. However, no. 1 contradicts this suggestion. It has an arched tilt that must

\footnotetext{
${ }^{27}$ However see the bull found around Alaca Höyük (Ar1k 1937, pl. CCLXXI, no. 1080 below) and from Horoztepe (Özgüç - Akok 1958, 17-19, pl. XI/2). See also Littauer - Crouwel 1973, 120.

${ }^{28}$ According to Littauer and Crouwel, this richness which is also seen on other models, may demonstrate that they all were not produced in the same workshop or by the same artisan: Littauer Crouwel 1973, 121.

${ }^{29}$ Ibid. 107.
} 
have been designed to give shelter against the weather. ${ }^{30}$ It also could be used for human transportation, as found in modern times. Slow-paced bovid draught would have been more appropriate for this intention rather than faster equid draught. Unfortunately, there is no evidence on the Abamor models about the driver or the load they carried.

The conceivable functions of these models were widely discussed by Littauer and Crouwel. ${ }^{31}$ They might have been substitutes for full-size vehicles that were buried with their owners, probably for use in another world. $^{32}$ Other models found in tombs at various sites strengthen this view and oppose the idea that they were simply toys. ${ }^{33}$

The historical development of wheeled vehicles has been widely discussed by Littauer and Crouwel. $^{34}$ The evidences appear as pictographic representation from the late fourth millennium B.C. From the Early Dynasty II period and later, representational and archaeological material evidence of fourwheeled vehicles is widely existent in Mesopotamia and environs. ${ }^{35}$ However, from this time span there is no distinct archaeological nor representational evidence specifying the wheeled transportation in Anatolia. $^{36}$ The Acemhöyük cart, the representations in glyptic art from the Assyrian Colony Period, as well as the written evidences are the first such clues in Anatolia. In this period, we know that wagons drawn by oxen or donkeys were used for the transportation of goods. ${ }^{37}$

\footnotetext{
${ }^{30}$ Littauer - Crouwel 1974, 28

${ }^{31}$ Littauer - Crouwel 1973, 125; Littauer - Crouwel 1974, 25.

32 Littauer - Crouwel 1973, 102; Piggott 1968, 273; Strommenger 1990, 299; Moorey 2001, 346; see also Orthmann 1967.

${ }^{33}$ Littauer - Crouwel 1974, 25; see also Cholidis 1989.

${ }^{34}$ Littauer - Crouwel 1973, 108.

35 Watelin 1934, 30 ff; see also, Piggott 1968, 272 for brief explanations.

${ }^{36}$ See note 27

${ }^{37}$ See Dercksen 1996, 64-67; Özgüç 2001.
}

Taking into consideration that the terracotta models of the four-wheeled vehicles especially similar to the Abamor model no. 1 in shape, which were found in well-dated context in various sites, the metal models discovered in Abamor, may also be dated to the late third and early second millennium BC. ${ }^{38}$

Dr. Fikri Kulakoğlu, Ankara University, Faculty of Letters Department of Near Eastern Archaeology, 06100 Sihhiye / Ankara

e-mail: kulakoglu@yahoo.com

\section{List of Figures}

Map 1. Abamor and its environment.

Figure 1. Abamor bronze wagon models.

Figure 2. Abamor model no 1.

Figure 3. Abamor model no. 1, detail.

Figure 4. Bull of Abamor no. 1.

Figure 5. Abamor model no. 2.

Figure 6. Abamor model no. 2, detail.

Figure 7. Abamor model no. 2, detail.

Figure 8. Bull of Abamor no.2.

Figure 9. Abamor model no. 3 .

Figure 10. Abamor model no. 3, detail.

Figure 11. Abamor model no. 3, detail.

Figure 12. Bull of Abamor no. 3. 


\section{Bibliography}

Arık 1937

Bollweg 1999

Cholidis 1989

Dercksen 1996

Liebowitz 1988

Littauer - Crouwel 1973

Littauer - Crouwel 1974

Littauer - Crouwel 1990

Littauer et al. 2002

Moorey 2001

Orthmann 1967

Özgen 1986

Özgüç - Akok 1958

Özgüç 2001

Piggott 1968

Speiser 1935

Strommenger - Kohlmeyer

1998

Strommenger et al. 1987

Strommenger 1990

Watelin 1934

Zettler 1996
R. O. Arık, Les fouilles d'Alaca Höyük (1937).

J. Bollweg, Vorderasiatische Wagentypen (1999).

N. Cholidis, "Tiere und tierförmige Gefäse auf Rädern Gedanken zum Spielzeug im alten Orient", MDOG 121 (1989) 197-220.

J. D. Dercksen, The Old Assyrian Copper Trade in Anatolia (1996).

H. Liebowitz, Terra Cotta Figurines and Model Vehicles (1988).

M. A. Littauer - J. H. Crouwel, "Early Metal Models of Wagons from the Levant", Levant 5 (1973) 102-126.

M. A. Littauer - J. H. Crouwel, "Terracotta Models as Evidence for Vehicles with Tilts in the Ancient Near East", Proceedings of the Prehistoric Society 40 (1974) 20-36.

M. A. Littauer - J. H. Crouwel, "A Terracotta Wagon Model from Syria in Oxford", Levant 22 (1990) 160-162.

M. A. Littauer - J. H. Crouwel - P. Raulwing, "Selected Writings on Chariots and Other Early Vehicles, Riding and Harness", Culture and History of the Ancient Near East 6 (2002).

P. R. S. Moorey, "Clay Models and Overland Mobility in Syria, c. 2350-1800 B.C", in: J.-W. Meyer -M. Novak - A. Pruss (Hrsg.) Beiträge zur Vorderasiatischen Archäologie Winfried Orthmann gewidmet (2001) 344-349.

W. Orthmann, , 'Zu den 'Standarten' aus Alaca Hüyük”, IstMitt. 17 (1967) 34-54.

E. Özgen, "A Group of Terracotta Wagon Models from Southeastern Anatolia", AnatSt. 36 (1986) 165-171.

T. Özgüç - M. Akok, Horoztepe: Eski Tunç Devri Mezarlı̆̆ «skan Yeri/An Early Bronze Age Settlement and Cemetery (1958).

N. Özgüç. "Notes on the Bronze Vehicle from the Sarıkaya Palace at Acemhöyük", in: W.H. van Soldt (ed.), Veenhof Anniversary Volume. Studies Presented to Klaas R. Veenhof on the Occasion of the Sixty-Fifth Birthday (2001) 361-366.

S. Piggott, "The Earliest Wheeled Vehicles and the Caucasian Evidence", Proceedings of the Prehistoric Society NS 34 (1968) 266-318.

E. A. Speiser, Excavations at Tepe Gawra (1935).

E. Strommenger - K. Kohlmeyer, Tall Bi'a/Tuttul-I. WVDOG 96 (1998).

E. Strommenger - C. Hemker - K. Kohlmeyer - W. Mayer - L. Nabo - K. Pütt - D. Rittig - E. Schneiders, “Ausgrabungen in Tall Bi'a 1985”, MDOG 119 (1987) 750 .

E Strommenger, "Planwagen aus dem Mittleren Euphrattal", in: P. Matthiae - M. van Loon - H. Weiss (Hrsg.), Resurrecting the Past. A Joint Tribute to A. Bounni (1990) 297-301.

L. Watelin, Excavations at Kish IV (1934).

R. L. Zettler, “Tell es -Sweyhat, 1989-1995”, Expedition 38.1 (1996) 14-26. 


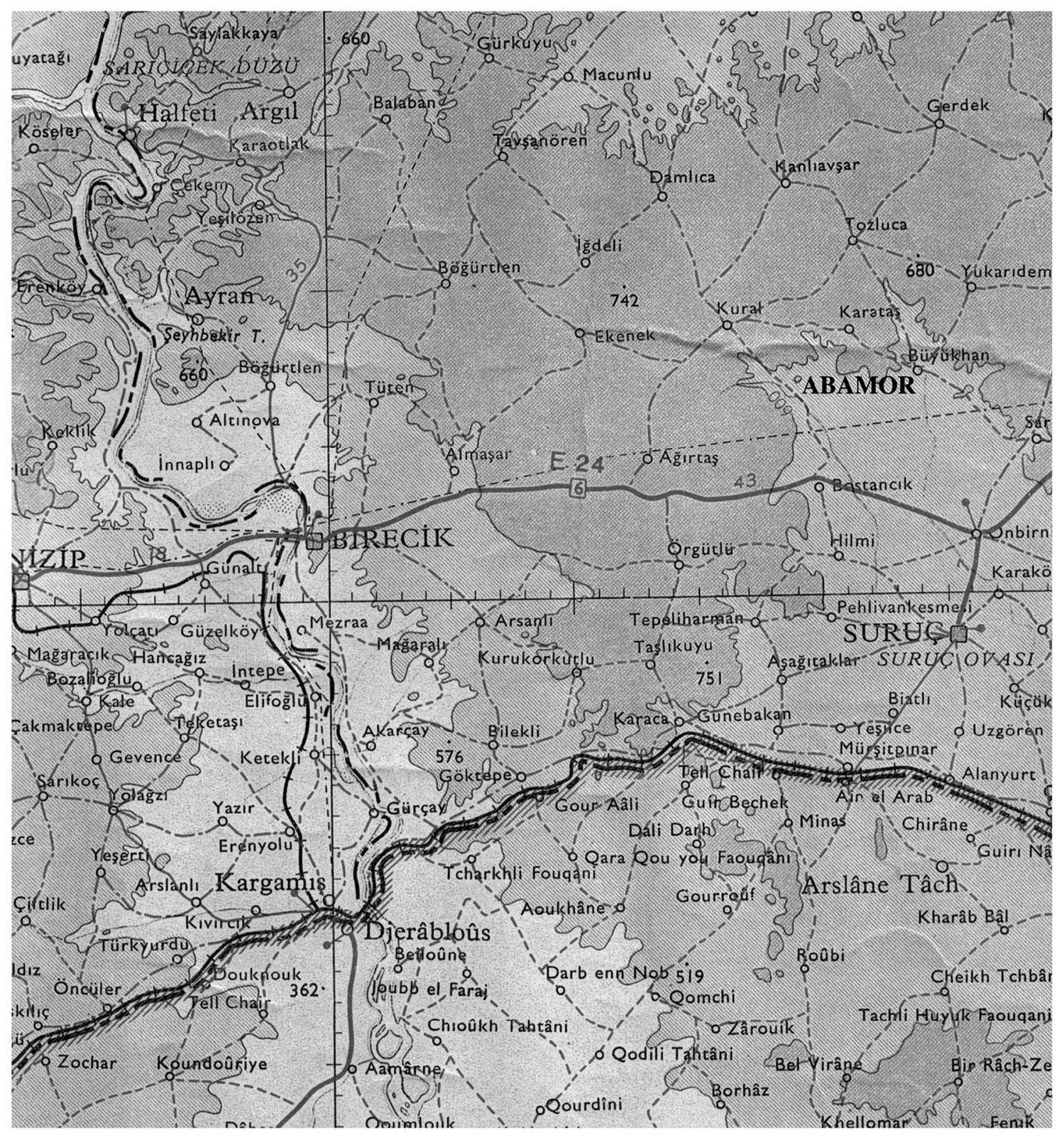

Map 1 
Recently Discovered Bronze Wagon Models from Şanlurfa, Southeastern Anatolia

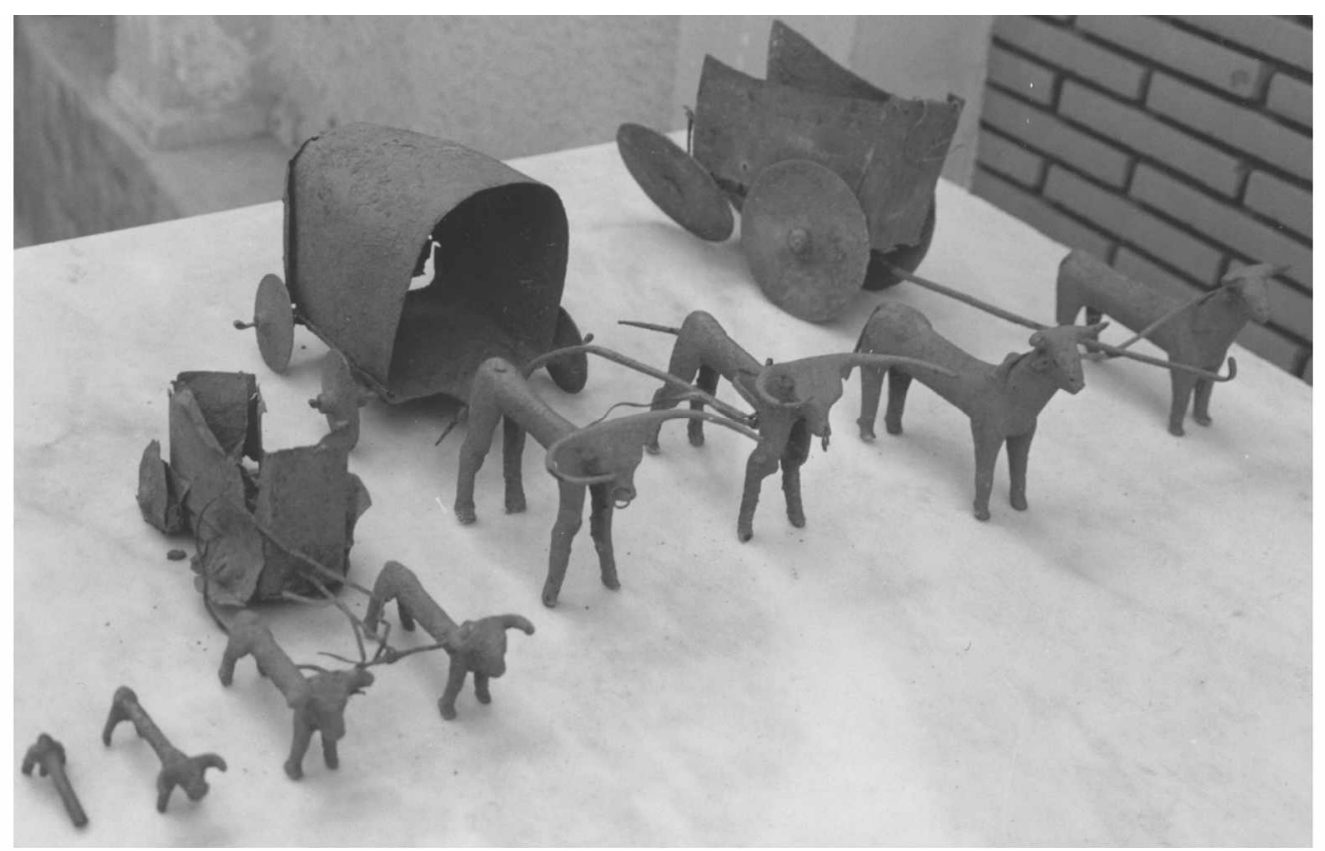

Figure 1

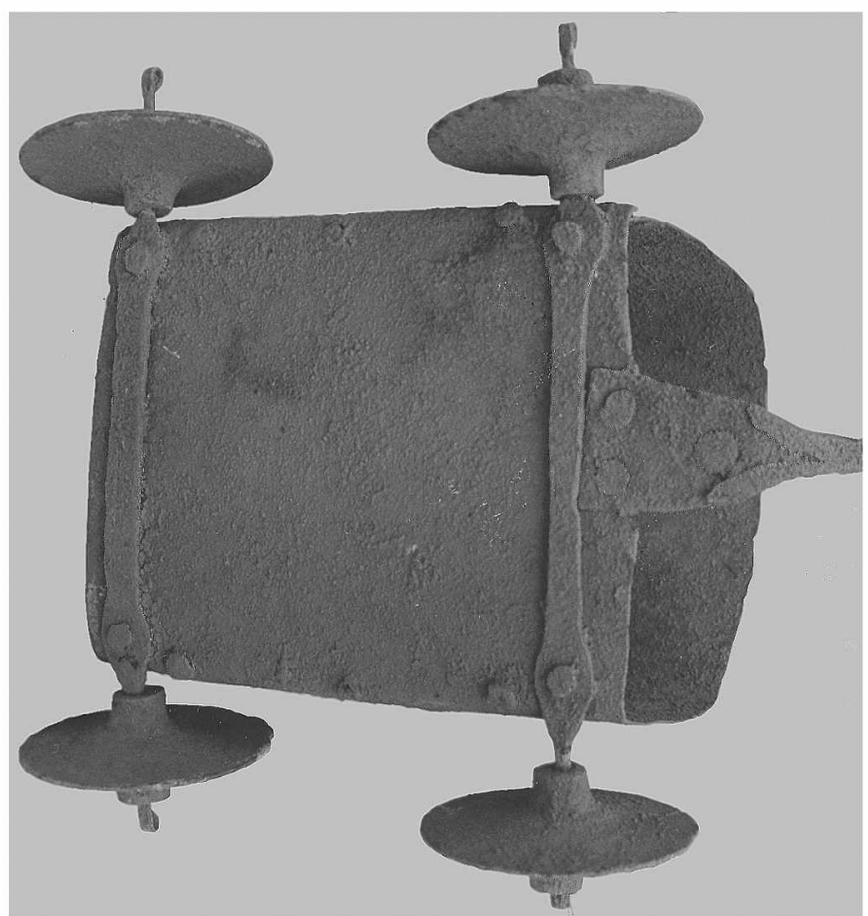

Figure 2 


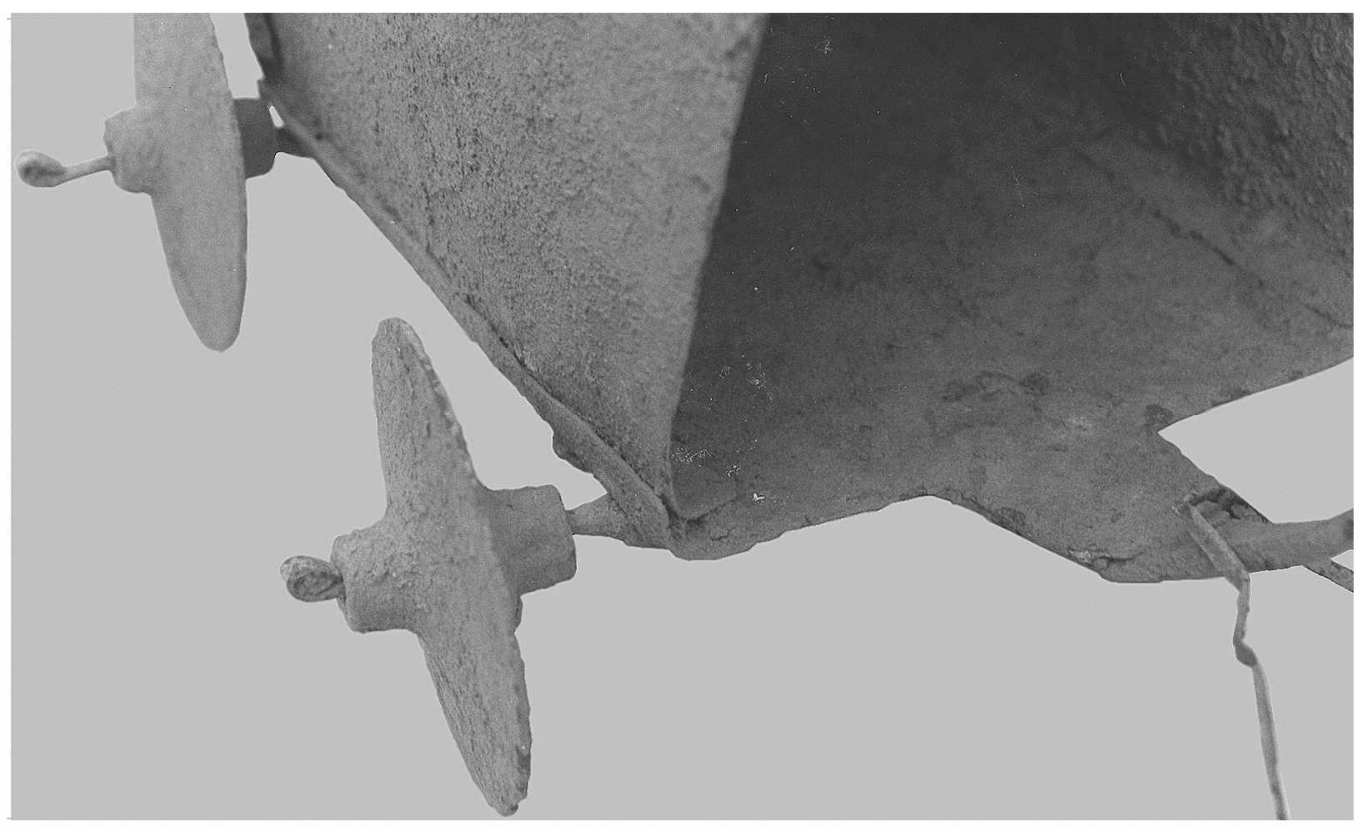

Figure 3

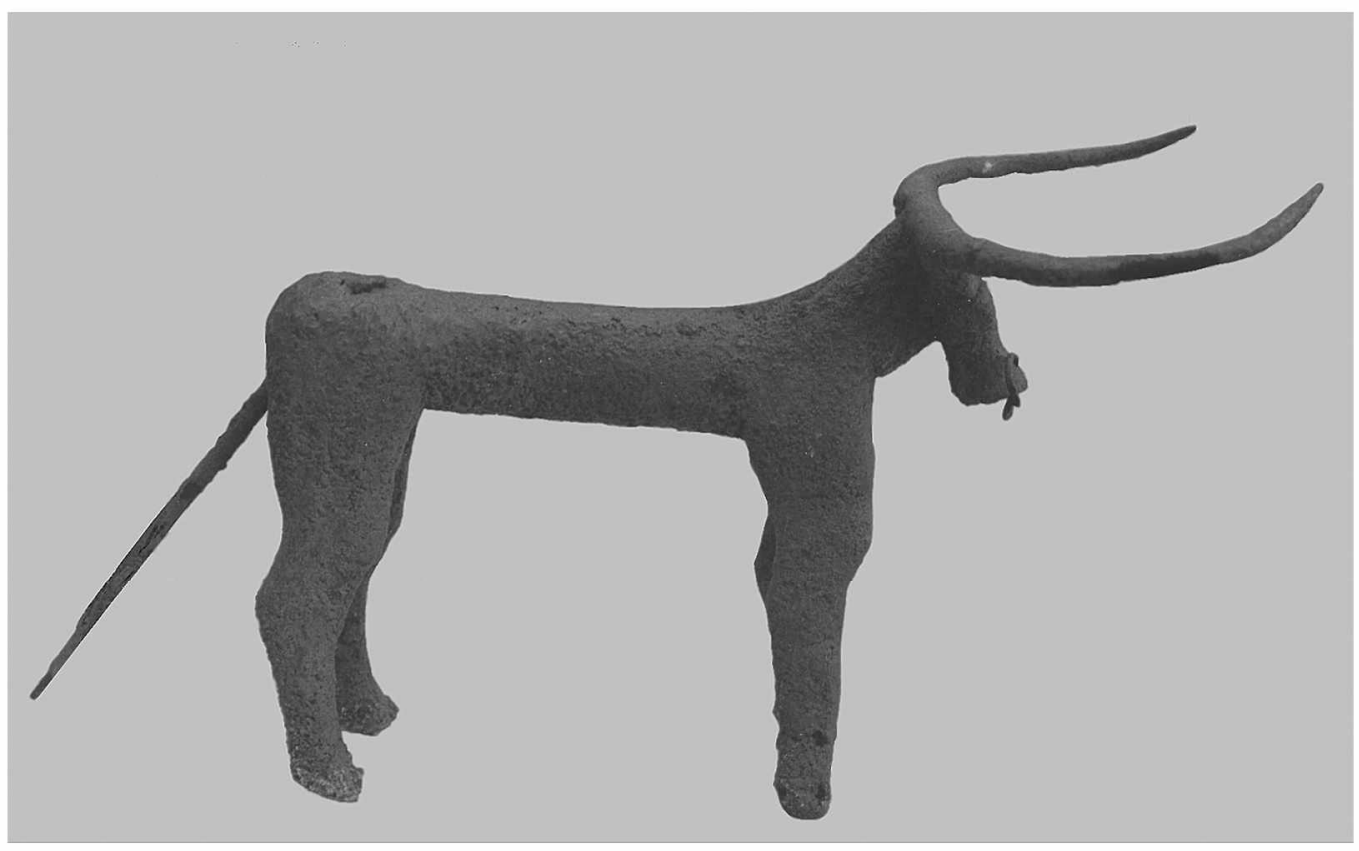

Figure 4 
Recently Discovered Bronze Wagon Models from Şanlurfa, Southeastern Anatolia

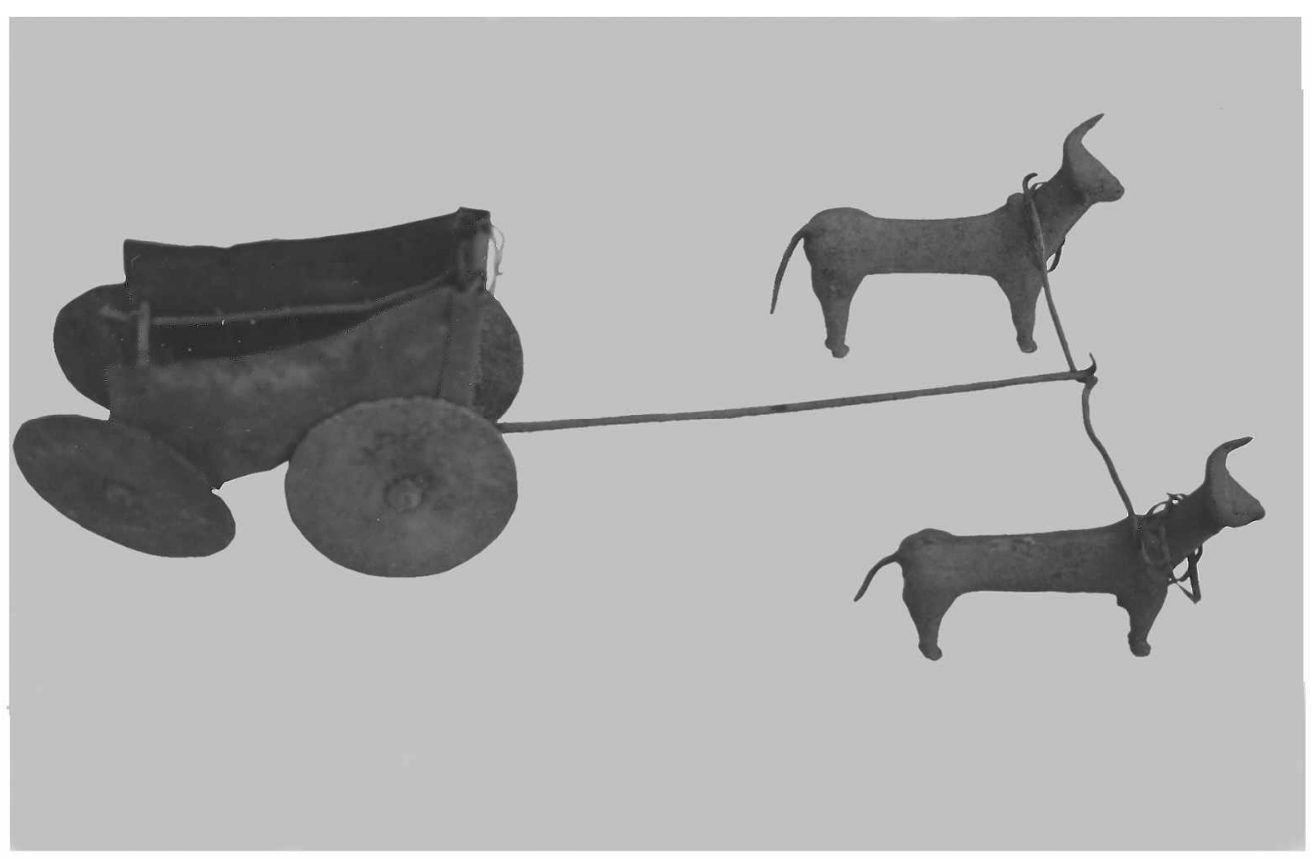

Figure 5

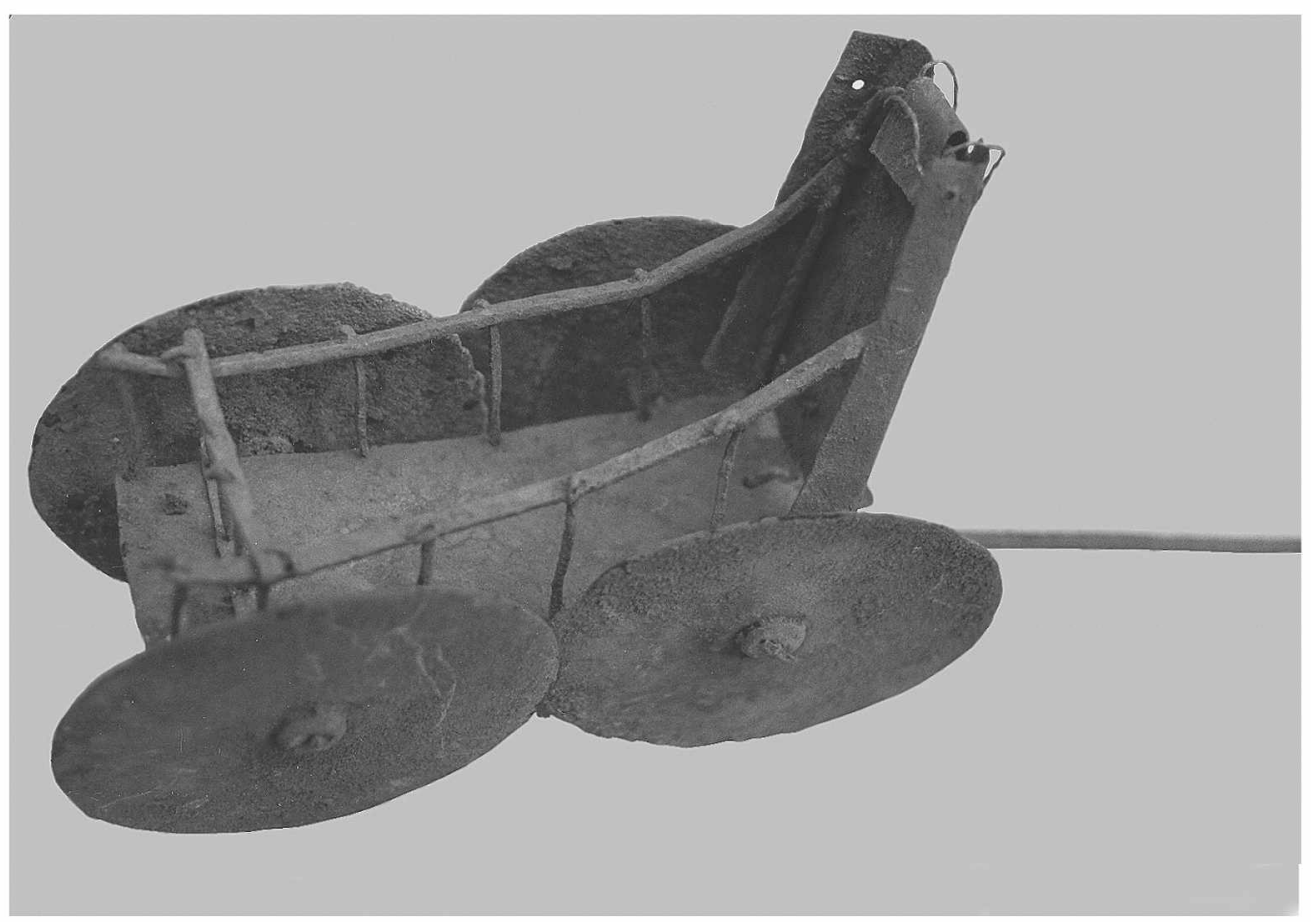

Figure 6 


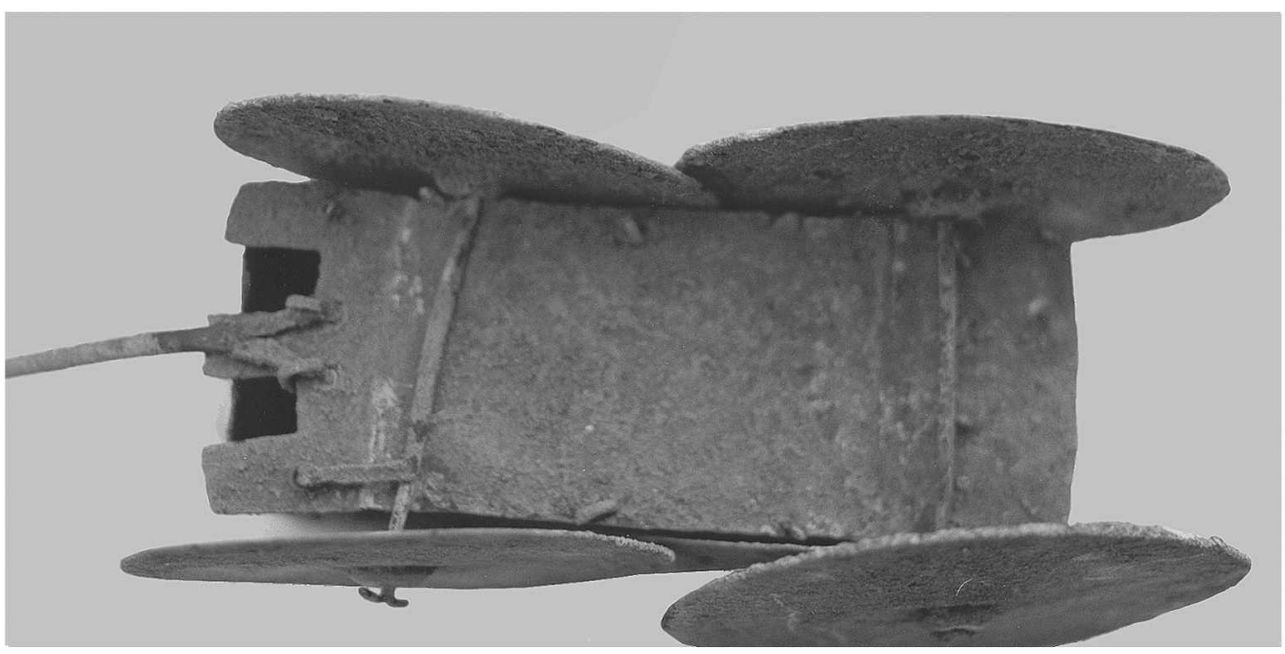

Figure 7

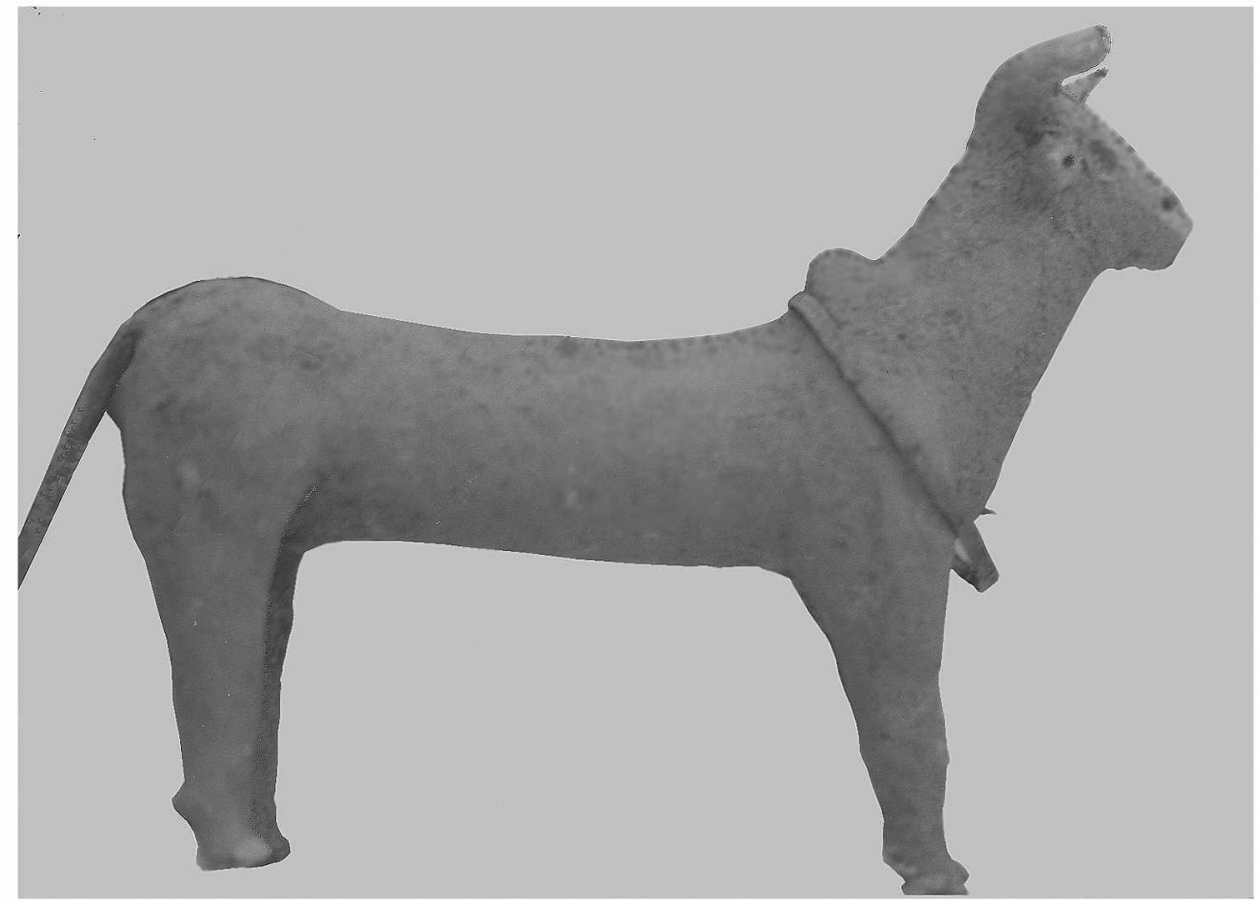

Figure 8 
Recently Discovered Bronze Wagon Models from Şanlurfa, Southeastern Anatolia

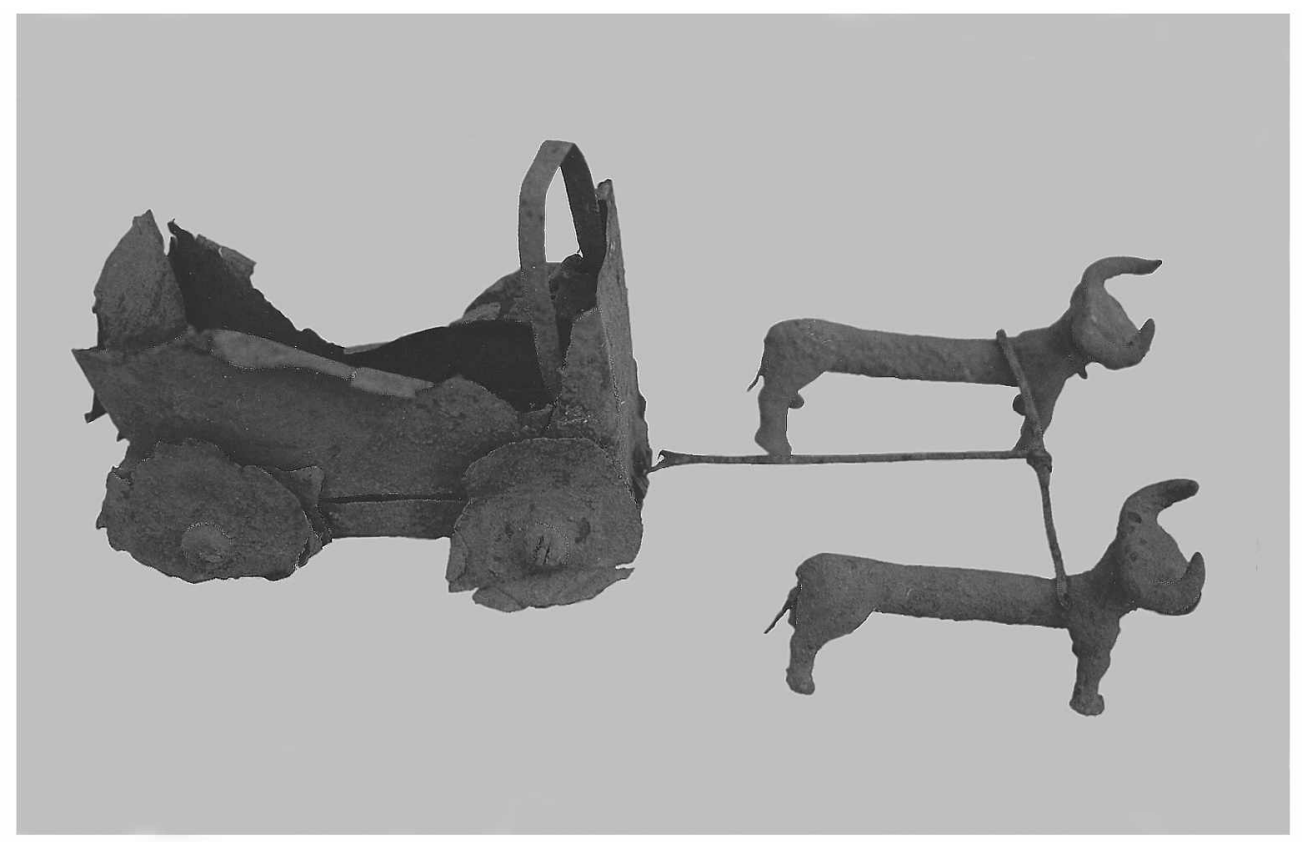

Figure 9

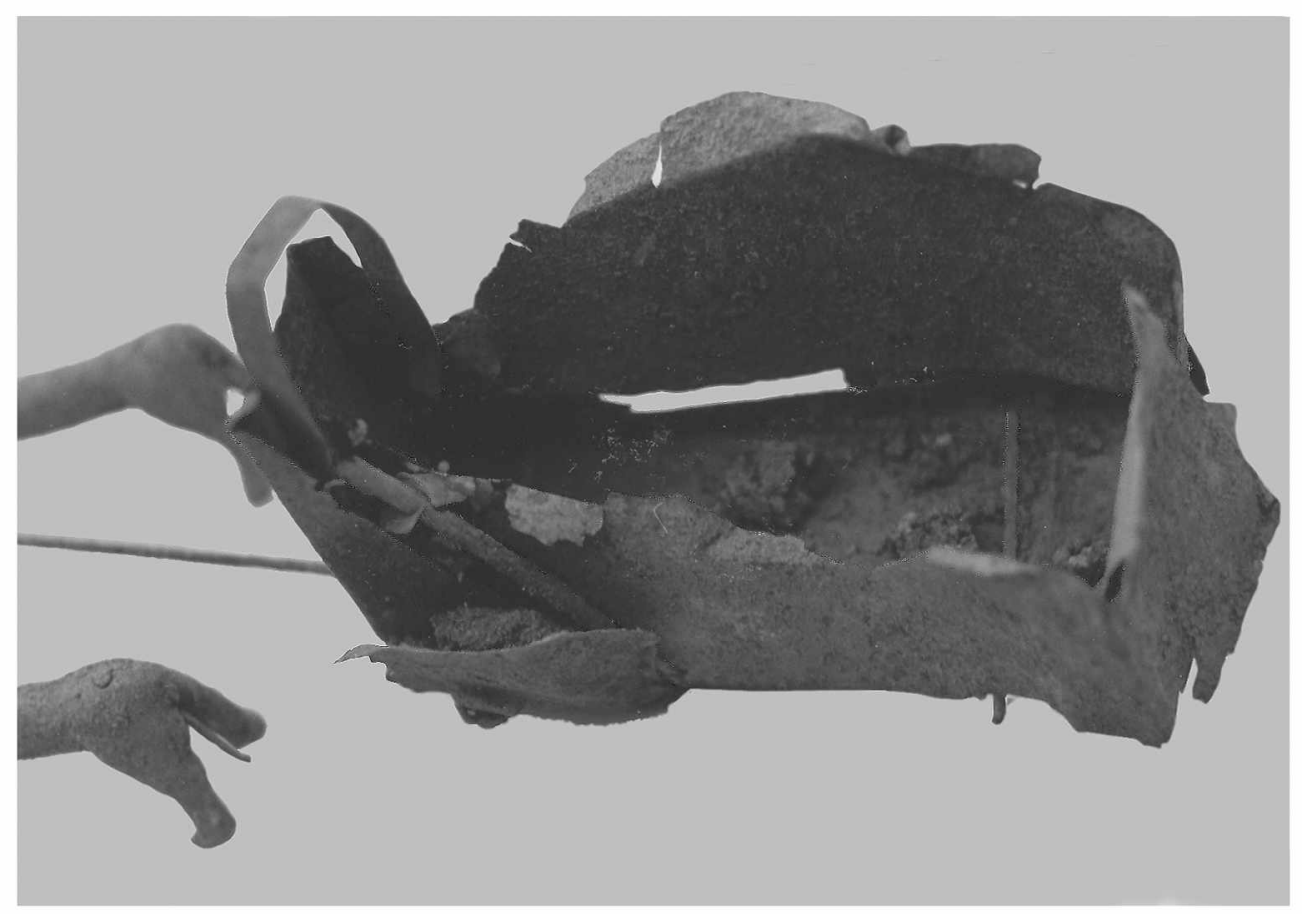

Figure 10 


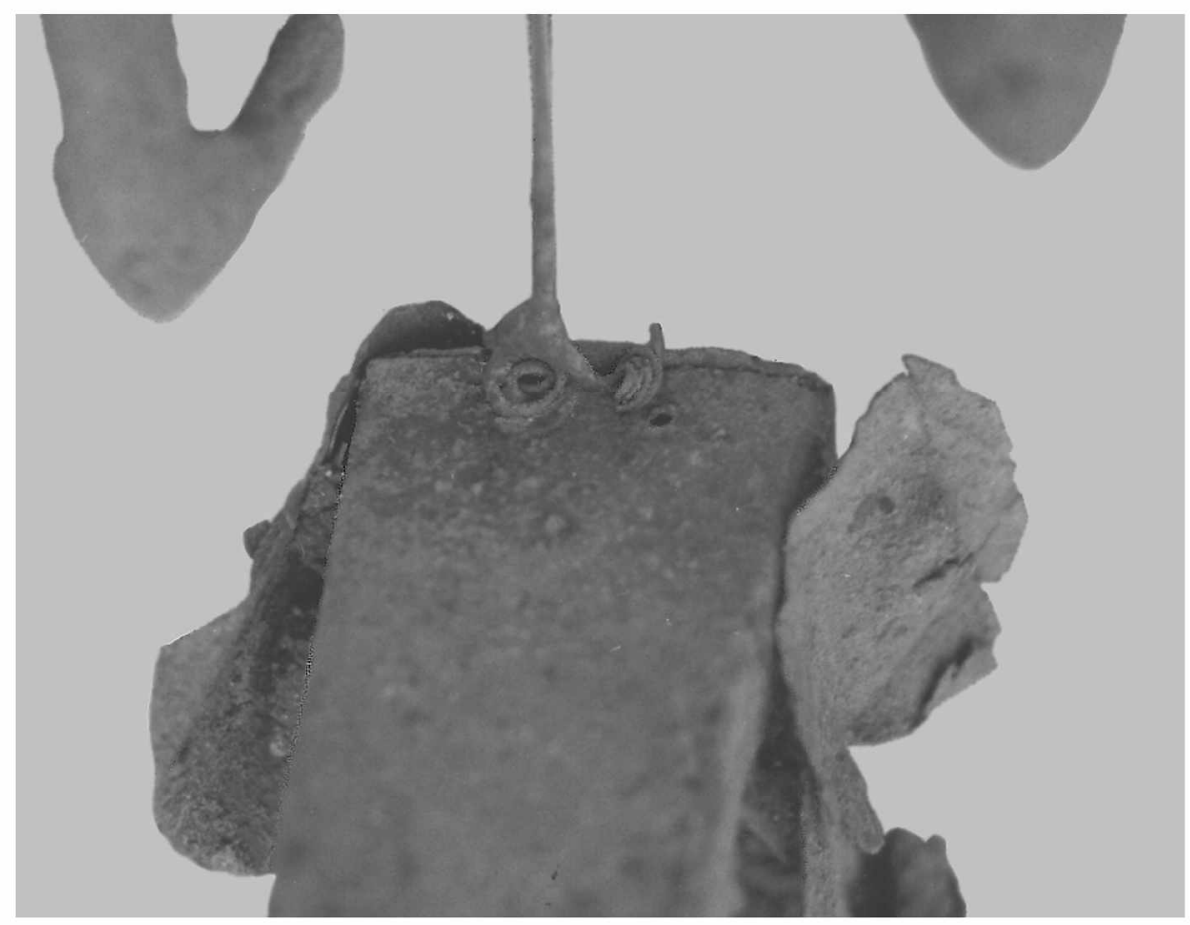

Figure 11

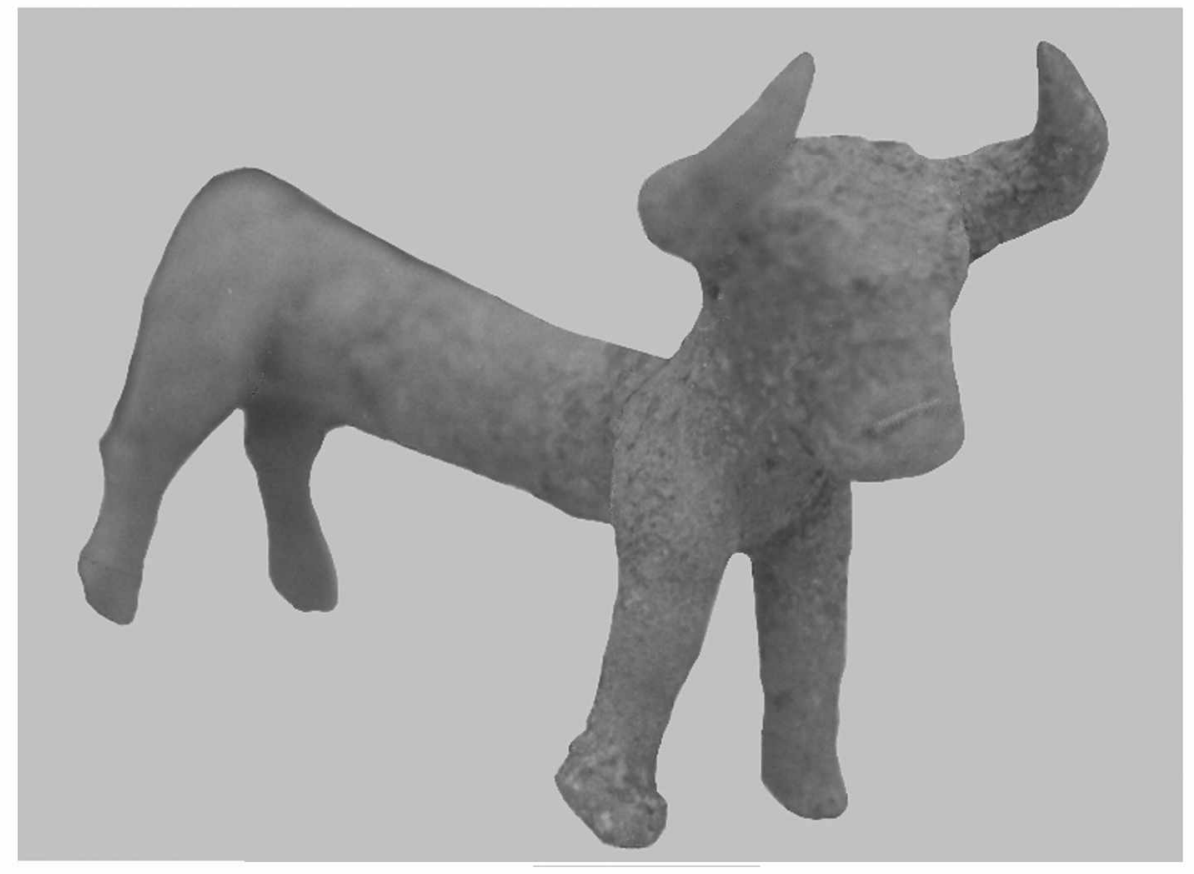

Figure 12 